\title{
The effect of mobile phone waves on salivary secretion in dental students of Rafsanjan University of Medical Sciences
}

\author{
N. Kamyab' ${ }^{1}$ Z. Mordouei², M. Hosseini' ${ }^{1}$ M. Sheikh Fathollahi3 ${ }^{*}$ \\ ${ }^{1}$ Department of Oral and Maxillofacial Medicine, Faculty of Dentistry, Rafsanjan University of Medical Sciences, \\ Rafsanjan, Iran \\ ${ }^{2}$ Epidemiology Department, Rafsanjan University of Medical Sciences, Rafsanjan, Iran \\ ${ }_{3}^{3}$ Department of Epidemiology and Biostatistics and Occupational Environment Research Center, School of \\ Medicine, Rafsanjan University of Medical Sciences, Rafsanjan, Iran
}

\section{- Original article}

\section{*Corresponding authors: \\ M. Sheikh Fathollahi, PhD., \\ E-mail: \\ mamoosh502002@yahoo.com}

Revised: February 2020

Accepted: February 2020

Int. J. Radiat. Res., January 2021; 19(1): $81-87$

DOI: 10.29252/ijrr.19.1.81

\begin{abstract}
Background: Excessive use of mobile phones is addictive and causes many complications. The severity of these complications depends on the duration of the call and the frequency of using mobile phones. Therefore, this study aimed to determine the effect of mobile phone waves on salivary secretion. Materials and Methods: This descriptive study was conducted on 120 dental students in Rafsanjan, Iran, in 2015. Using the call history of the mobile phones, the number and duration of each person's daily calls were obtained. The spitting method was used to collect unstimulated saliva, and stimulated saliva was collected with the help of natural chewing gums without sugar and additive flavors. After sampling, the falcon tubes containing saliva were centrifuged at $2500 \mathrm{rpm}$ for 10 minutes. Then the saliva volume was read from the tube and recorded. Independent two-sample t test, one-way ANOVA, and multiple linear regression model were used for data analysis. Results: Students who talked for more than 40 minutes or 20-40 minutes a day on their mobile phones had a mean unstimulated salivary secretion of 0.885 and $0.331 \mathrm{ml} / \mathrm{min}$, respectively and mean stimulated salivary secretion of 0.702 and $0.708 \mathrm{ml} / \mathrm{min}$, respectively more than students who talked less than 20 minutes a day on their cell phones $(P<0.05)$. Conclusion: The results showed that increased duration of cell phone calls was associated with increasing the amount of stimulated and unstimulated salivary secretion, which could decrease the risk of developing oral infections and tooth decay.
\end{abstract}

Keywords: Mobile phone, stimulated salivary secretion, unstimulated salivary secretion, dental students.

\section{INTRODUCTION}

Mobile phone technology has created a lot of changes in the lifestyle of people (1). The expansion of mobile networks and the variety of services provided by the service providers of these networks have increased the popular acceptance of the use of this device (2). The prevalence of mobile phone use has grown steadily over the last two decades (3). In 2014, the number of cell phone users in the world was 1.85 billion people, which is estimated to increase to 2.87 billion people by 2020 (4). Also, every Spanish uses his/her mobile phone for an average of 3.5 hours per day (5). The prevalence of mobile phone use among teenagers and young people in South India has been reported to be between $1.5 \%$ and $24.2 \%$ (6).

Excessive use of the mobile phone is addictive and causes complications such as headache, neck pain, anxiety, fatigue, depression, disturbed sleeping and concentration, memory weakness, and heat in the ears $(7,8)$. It should be noted that the severity 
of these complications depends on the duration of the calls and the frequency of use of the mobile phone ${ }^{(9)}$. Also, the waves emitted from mobile phones can cause a genetic defect or lead to cancer by affecting chromosomes (10-12).

Given that the mobile phone is placed close to the head, the radio waves produced by it may affect the brain and other tissues in the head area (13). Therefore, there are always concerns about the effects of these waves as stimuli of tumor formation or any other adverse effects on health (14). Parotid glands are the largest salivary glands located in front of each ear canal and behind the mandibular ramus, close to where the mobile phone is usually kept while talking (5). Since salivary glands play an important role in the health of the oral cavity, any factor that impairs the normal functioning of the salivary glands can place the oral cavity health at risk (15).

Despite the scattered efforts to examine the impact of mobile phone waves on human health, few studies have assessed the effect of mobile phones on the amount of salivary secretion (16). Since the waves emitted from cell phones have the ability to penetrate the tissues of the human body and destroy them (17), the present study aimed to determine the effect of mobile phone waves on salivary secretion in dental students of Rafsanjan University of Medical Sciences.

\section{MATERIALS AND METHODS}

This descriptive cross-sectional study was conducted to investigate the effect of mobile phone waves on salivary secretion in dental students admitted to the Rafsanjan University of Medical Sciences in 2015. The inclusion criterion was at least five years of mobile use, and exclusion criteria included alcohol consumption, smoking, chronic systemic disease (e.g. cancer, cardiovascular diseases, diabetes, etc.), history of surgery in the head and neck, trauma, dry mouth, history of chemotherapy and radiotherapy, pregnancy, having a supplemental diet, using hands-free, and periodontal pockets greater than $3 \mathrm{~mm}$.

A total of 120 students were selected by census method and examined as the statistical population. Informed consents were also obtained. The demographic data of students such as age, gender, year of entering university, mobile phone brand, and duration of conversation and frequency of making cell phones calls per day were collected and recorded in a checklist.

The number of calls and the duration of each conversation was obtained through checking the call history of subjects' mobile phones for the seven past days. Then, the mean duration and frequency of making cell phone calls in 24 hours was calculated. Participants were divided into three groups based on the average time of using mobile phones per day including those who used their mobile phones for less than 20 minutes, 20 -40 minutes, and over 40 minutes. Also, these people were divided into three groups in terms of frequency of making cell phone calls including using less than 3 times, 3-5 times, and more than 5 times per day (16). This information was then added to the checklist for each person.

In order to collect the saliva of the subjects, they were asked to avoid eating, drinking and brushing their teeth about an hour before the sampling. Sampling was carried out at 9 to 11 am in order to have uniform sampling conditions. The unstimulated saliva of the samples was collected by spitting method and stored in special falcon tubes (Jet Biofil, Beijing, China). Hence, subjects were asked to spit their saliva into $15 \mathrm{cc}$ falcon tubes for two minutes. At the end of collecting unstimulated saliva, subjects were given one minute of rest and then stimulated saliva was collected. To do so, a natural chewing gum (Saghez Sazi Kurdistan (Van) Co., Sanandaj, Iran), without any sugar and flavoring additive, was given to each student to chew for stimulation of saliva and spit their saliva in $15 \mathrm{cc}$ falcon tubes for two minutes (16). Upon completion of the sampling, all tubes were immediately transferred to the laboratory of the medical school to be centrifuged. The tubes were then centrifuged at $2500 \mathrm{rpm}$ for 10 minutes (Kubota, Tokyo, Japan). Then the volume of saliva was read from the tube and recorded in the relevant checklist in $\mathrm{ml} / \mathrm{min}$.

Data were analyzed using SPSS version 18 software (SPSS Inc., Chicago, IL, USA). 
Quantitative data were reported as mean \pm standard deviation (SD) and qualitative data were reported as number (percentage). One-way ANOVA was used to compare the mean volume of stimulated and unstimulated salivary secretion across students based on age, duration of mobile phones use, and frequency of making cell phone calls per day. Independent two-sample $t$ test was used to compare mean stimulated and unstimulated salivary secretion amount in students based on sex. Also, multiple linear regression model was used to predict the stimulated and unstimulated salivary secretion in terms of age, sex, duration and frequency of making cell phone calls per day. Significance level was set at 0.05 .

\section{RESULTS}

The present study was conducted on 120 dental students. The mean and standard deviation of students' age was $21.71 \pm 1.67$ ranged from 18 to 25 years old, and 44 (36.7\%) of them were male and $76(63.3 \%)$ were female. The frequent number of participants had entered university in 2010 (24, 20\%). Among the students, 38 (31.7\%) had Samsung mobile phones and only one $(0.8 \%)$ of the students had a Nokia cell phone. Also, 54 (45\%) of the participants made cell phone calls 3 times a day at most, and 65 (54.2\%) of them had a maximum talk time of 20 minutes per day (table 1).

Table 2 shows the mean stimulated and unstimulated salivary secretion in students in terms of age, sex, duration, and frequency of making mobile phone calls per day.

The results of table 2 show that increasing the duration and frequency of making mobile phone calls per day increases the mean stimulated and unstimulated salivary secretion.

A multiple linear regression model was used to predict the mean stimulated and unstimulated salivary secretion $(\mathrm{ml} / \mathrm{min})$ based on variables of age, sex, duration and frequency of making mobile phone calls per day (tables 3 and 4).

Non-parametric Kolmogorov-Smirnov test indicated that the frequency distribution of

Int. J. Radiat. Res., Vol. 19 No. 1, January 2021

unstimulated saliva was distributed normally $(\mathrm{P}=0.721)$. The value of the Durbin-Watson statistic was 1.885 , and since this statistic is between 1.5 and 2.5, the assumption of independence of residuals is established. The histogram of residuals depicted a normal distribution with a mean of zero. Also, the P-P plot suggested that the residuals were distributed normally. The ZRRED versus ZRESID plot did not reveal a clear pattern indicating the uniform distribution of points on the regression plane. The value of the condition index was less than 5 , indicating no significant multicollinearity between independent variables.

Multiple linear regression analysis for prediction mean unstimulated salivary secretion (ml/min) was statistically significant with degrees of freedom 7 and 112 and $F=24.033$ and $\mathrm{P}<0.001$.

Table 1. Frequency distribution of demographic variables of dental students of Rafsanjan University of Medical Sciences in $2015(N=120)$.

\begin{tabular}{|c|c|c|}
\hline Variable & Number & Percent \\
\hline $\begin{array}{l}\text { Age (year) } \\
18-20 \\
21-22 \\
23-25\end{array}$ & $\begin{array}{l}29 \\
45 \\
46\end{array}$ & $\begin{array}{l}24.2 \\
37.5 \\
38.3\end{array}$ \\
\hline $\begin{array}{c}\text { Gender } \\
\text { Male } \\
\text { Female }\end{array}$ & $\begin{array}{l}44 \\
76\end{array}$ & $\begin{array}{l}36.7 \\
63.3\end{array}$ \\
\hline $\begin{array}{c}\text { Year of university } \\
\text { entrance } \\
2009 \\
2010 \\
2011 \\
2012 \\
2013 \\
2014 \\
2015\end{array}$ & $\begin{array}{c}1 \\
24 \\
21 \\
22 \\
17 \\
20 \\
15\end{array}$ & $\begin{array}{c}0.8 \\
20.0 \\
17.5 \\
18.3 \\
14.2 \\
16.7 \\
12.5\end{array}$ \\
\hline $\begin{array}{c}\text { Type of phone } \\
\text { Nokia } \\
\text { Sony } \\
\text { HTC } \\
\text { Apple } \\
\text { Samsung } \\
\text { Huawei } \\
\text { LG }\end{array}$ & $\begin{array}{c}1 \\
28 \\
15 \\
10 \\
38 \\
22 \\
6\end{array}$ & $\begin{array}{c}0.8 \\
23.3 \\
12.5 \\
8.3 \\
31.7 \\
18.3 \\
5.0\end{array}$ \\
\hline $\begin{array}{l}\text { Per day call } \\
<20 \mathrm{~min} \\
20-40 \mathrm{~min} \\
>40 \mathrm{~min}\end{array}$ & $\begin{array}{l}65 \\
32 \\
23\end{array}$ & $\begin{array}{l}54.2 \\
26.7 \\
19.2\end{array}$ \\
\hline $\begin{array}{c}\text { NO. of call per day } \\
<3 \text { times } \\
3-5 \text { times } \\
>5 \text { times }\end{array}$ & $\begin{array}{l}54 \\
45 \\
21\end{array}$ & $\begin{array}{l}45.0 \\
37.5 \\
17.5\end{array}$ \\
\hline
\end{tabular}


Table 2. Comparison of the mean stimulated and unstimulated salivary secretion $(\mathrm{ml} / \mathrm{min})$ in terms of the variables studied in dental students of Rafsanjan University of Medical Sciences in 2015 ( $N=120)$.

\begin{tabular}{|c|c|c|c|c|}
\hline Variable & Unstimulated Saliva Mean \pm SD & P-value & Stimulated Saliva Mean \pm SD & P-value \\
\hline $\begin{array}{c}\text { Age (year) } \\
18-20(n=29) \\
21-22(n=45) \\
23-25(n=46)\end{array}$ & $\begin{array}{l}2.01 \pm 0.37 \\
1.97 \pm 0.45 \\
1.99 \pm 0.43\end{array}$ & 0.911 & $\begin{array}{l}5.15 \pm 1.06 \\
5.42 \pm 0.68 \\
5.27 \pm 0.83\end{array}$ & 0.368 \\
\hline $\begin{array}{c}\text { Gender } \\
\text { Male }(n=44) \\
\text { Female }(n=76)\end{array}$ & $\begin{array}{l}1.95 \pm 0.47 \\
2.01 \pm 0.40\end{array}$ & 0.524 & $\begin{array}{l}5.52 \pm 0.56 \\
5.16 \pm 0.93\end{array}$ & 0.008 \\
\hline $\begin{array}{c}\text { Per day call } \\
<20 \min (n=65) \\
20-40 \min (n=32) \\
>40 \min (n=23)\end{array}$ & $\begin{array}{l}1.75 \pm 0.27 \\
2.06 \pm 0.19 \\
2.57 \pm 0.43\end{array}$ & $<0.001$ & $\begin{array}{l}4.92 \pm 0.71 \\
5.72 \pm 0.72 \\
5.77 \pm 0.78\end{array}$ & $<0.001$ \\
\hline $\begin{array}{l}\text { NO. of call per day } \\
<3 \text { times }(n=54) \\
3-5 \text { times }(n=45) \\
>5 \text { times }(n=21)\end{array}$ & $\begin{array}{l}1.84 \pm 0.34 \\
2.02 \pm 0.40 \\
2.29 \pm 0.53\end{array}$ & $<0.001$ & $\begin{array}{l}5.06 \pm 0.86 \\
5.37 \pm 0.78 \\
5.76 \pm 0.62\end{array}$ & 0.003 \\
\hline
\end{tabular}

Table 3. Regression coefficients for predicting the mean unstimulated salivation ( $\mathrm{ml} / \mathrm{min}$ ) in dental students of Rafsanjan University of Medical Sciences in 2015 ( $\mathrm{N}=120)$.

\begin{tabular}{|c|c|c|c|c|c|}
\hline Variable & $\begin{array}{c}\text { Unstandardized } \\
\text { Coefficient B }\end{array}$ & $\begin{array}{l}\text { Standardized } \\
\text { Coefficient Beta }\end{array}$ & 95\% Confidence Interval for B & $t$ & P-value \\
\hline Constant & 1.830 & - & $1.707,1.953$ & 29.473 & $<0.001$ \\
\hline $\begin{array}{c}\text { Age (year) } \\
18-20 \\
21-22 \\
23-25\end{array}$ & $\begin{array}{c}\text { ref. } \\
-0.074 \\
-0.052\end{array}$ & $\begin{array}{c}- \\
-0.084 \\
-0.059\end{array}$ & $\begin{array}{c}- \\
-0.209,0.062 \\
-0.019,0.084\end{array}$ & $\begin{array}{c}- \\
-1.072 \\
-0.756\end{array}$ & $\begin{array}{c}- \\
0.286 \\
0.451\end{array}$ \\
\hline $\begin{array}{c}\text { Gender } \\
\text { Male vs Female }\end{array}$ & -0.101 & -0.114 & $0.209,0.008$ & -1.841 & 0.068 \\
\hline $\begin{array}{l}\text { Per day call } \\
<20 \mathrm{~min} \\
20-40 \mathrm{~min} \\
>40 \mathrm{~min}\end{array}$ & $\begin{array}{c}\text { ref. } \\
0.331 \\
0.885\end{array}$ & $\begin{array}{c}- \\
0.344 \\
0.806\end{array}$ & $\begin{array}{c}- \\
0.204,0.457 \\
0.730,1.041\end{array}$ & $\begin{array}{c}- \\
5.187 \\
11.278\end{array}$ & $\begin{array}{c}- \\
<0.001 \\
<0.001\end{array}$ \\
\hline $\begin{array}{c}\text { NO. of call per day } \\
<3 \text { times } \\
3-5 \text { times } \\
>5 \text { times }\end{array}$ & $\begin{array}{l}\text { ref. } \\
-0.011 \\
-0.011\end{array}$ & $\begin{array}{c}- \\
-0.013 \\
-0.010\end{array}$ & $\begin{array}{c}- \\
-0.131,0.108 \\
-0.174,0.152\end{array}$ & $\begin{array}{c}- \\
-0.190 \\
-0.133\end{array}$ & $\begin{array}{c}- \\
0.850 \\
0.895\end{array}$ \\
\hline
\end{tabular}

R2 $=60.2 \%$, Adjusted R2 = 57.7\%

The results showed that stimulated salivary secretion in students who talk on their mobile phones for 20-40 minutes a day was averagely $0.708 \mathrm{ml} / \mathrm{min}$ further those who talk on their mobile phones for less than 20 minutes a day. Also stimulated salivary secretion in students who talk on their mobile phones for more than
40 minutes a day was averagely $0.702 \mathrm{ml} / \mathrm{min}$ further those who talk on their mobile phones for less than 20 minutes a day. In addition, the examined variables explain $29.6 \%$ of stimulated salivary secretion variations, the most powerful of which was the variable of duration of talk on mobile phone per day. 
Table 4. Regression coefficients for predicting the mean stimulated salivation ( $\mathrm{ml} / \mathrm{min}$ ) in dental students of Rafsanjan University of Medical Sciences in 2015 ( $N=120)$.

\begin{tabular}{|c|c|c|c|c|c|}
\hline Variable & $\begin{array}{l}\text { Unstandardized } \\
\text { Coefficient B }\end{array}$ & $\begin{array}{l}\text { Standardized } \\
\text { Coefficient Beta }\end{array}$ & $\begin{array}{l}\text { 95\% Confidence } \\
\text { Interval for B }\end{array}$ & $\mathbf{t}$ & P-value \\
\hline Constant & 4.686 & - & $4.374,4.997$ & 29.783 & $<0.001$ \\
\hline Age (year) & & & & & \\
\hline $18-20$ & ref. & - & - & - & - \\
\hline $21-22$ & 0.217 & 0.127 & $-0.130,0.563$ & 1.238 & 0.218 \\
\hline $23-25$ & 0.031 & 0.018 & $-0.315,0.377$ & 0.178 & 0.859 \\
\hline $\begin{array}{c}\text { Gender } \\
\text { Male vs Female }\end{array}$ & 0.263 & 0.153 & $-0.017,0.542$ & 1.863 & 0.065 \\
\hline Per day call & ref & 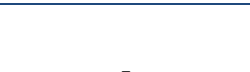 & 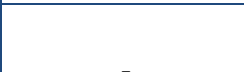 & 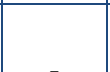 & - \\
\hline $20-40 \min$ & 0.708 & 0.379 & $0.382,1.033$ & 4.310 & $<0.001$ \\
\hline$>40 \mathrm{~min}$ & 0.702 & 0.334 & $0.314,1.091$ & 3.581 & 0.001 \\
\hline NO. of call per day & & & & & \\
\hline$<3$ times & ref. & - & - & - & - \\
\hline 3-5 times & 0.130 & 0.076 & $-0.175,0.434$ & 0.844 & 0.401 \\
\hline$>5$ times & 0.290 & 0.133 & $-0.123,0.704$ & 1.392 & 0.167 \\
\hline
\end{tabular}

\section{DISCUSSION}

Cell phones are one of the most commonly used devices that produce electromagnetic waves that are easily accessible to half of the world's population (3). The low frequency of electromagnetic radiation from high voltage power lines in mobile phone stations provide the grounds for brain cancers $(18,19)$. These waves also increase the risk of unilateral parotid gland cancers, in which the location of the tumor depends on the size of the mobile phone, the amount of its output force, and duration and frequency of making mobile phone calls (20). Despite the scattered efforts to examine the impact of mobile phone waves on human health, few studies have assessed the effect of mobile phones on the amount of salivary secretion (16). Therefore, the present study aimed at specifying the effects of mobile phone waves on salivary secretion in students.

In this study, mobile phones from Samsung and Sony brands were the most popular phones among students. In a study by De Souza et al., Samsung and Nokia brands were the most widely used (21). Probably the reason for choosing these companies is their brands, quality, performance, and variety in design and size of phones. The results also showed that students who talked for a long time on cell phones had higher amounts of stimulated and unstimulated salivary secretion. As the duration of conversations increased, the levels of unstimulated salivary also increased. In the case of stimulation of saliva, however, in addition to the duration of talking on the phone, there may be another affecting factor, natural gum for example, which causes saliva secretion itself.

The results of a study by Ranjitha et al. showed that the volume and speed of the blood flow of the external carotid artery, salivary secretion, and parotid gland protein concentration in the preferred head side of the mobile phone using students were significantly higher than their other side (22). A study by Goldwein et al. showed that salivary secretion in mobile phone using volunteers was significantly higher on the preferred side of head (23). Also, a study by Bhargava et al. showed a significant increase in salivary secretion and the flow and volume of blood in the parotid gland in the preferred head side of male and female users of mobile phones aged 18-30 years old (24). A study by Arbabi-Kalati et al. showed that salivary secretion increased in volunteers without oral lesions by increasing the duration of phone calls. 
They also addressed salivary antioxidant capacity in their study, and concluded that the salivary antioxidant capacity of individuals who had conversations for more than an hour was lower than those whose phone call duration were less than 20 minutes (16). The above studies are consistent with the present study.

In a study by Hamzany et al., all indices of salivary oxidative stress in mobile phone users significantly increased, while salivary secretion amount, total protein, albumin and amylase decreased (25). Also, in a study by Babaei et al., the relationship between conversation with mobile phones and the activity of alpha amylase enzymes in parotid glands in men and women aged 18-55 years old was not statistically significant. Their results indicated that the use of mobile phones did not affect the activity of the amylase parotid enzyme (26). The difference in result of the present study with the two above studies can be attributed to the difference in the statistical population, the age range of participants, the years of mobile use, and the variables measured.

In the present study, due to the selection of a community of young people aged 18-25, the long -term effects of mobile phone use were not explicitly investigated. Also, the measured variable was salivary secretion, the quantity of which was only studied, and not its quality. The amount of salivary secretion on the preferred head side of mobile phone users was not compared with that of the non-preferred side. Some students may have had diseases that directly or indirectly affected saliva, which they were unaware of.

\section{CONCLUSION}

The results of the present study indicated that increased duration of cell phone calls was correlated to increasing the amount of salivary secretion. It is suggested future studies be conducted on all age groups and in addition to quantity, the quality of saliva is examined. Measuring the amount of saliva secreted on the dominant side of cell phone use and compare it with the recessive side is also recommended.

\section{ACKNOWLEDGEMENT}

Thanks for funding from the Rafsanjan University of Medical Sciences due to financial support and all the participants who helped us to doing this study.

Funding: The authors have no disclosures of funding. This research was funded by Rafsanjan University of Medical Sciences. The Ethics Committee of Rafsanjan University of Medical Sciences, Rafsanjan, Iran, approved the study (IR.RUMS.REC.1394.25) on May 2015.

Conflicts of interest: Declared none.

\section{REFERENCES}

1. Dogan $M$, Turtay MG, Oguzturk $H$, Samdanci $E$, Turkoz $Y$, Tasdemir S, Alkan A, Bakir S (2012) Effects of electromagnetic radiation produced by $3 \mathrm{G}$ mobile phones on rat brains: magnetic resonance spectroscopy, biochemical, and histopathological evaluation. Human \& Exp toxico, 31 (6): 557-64.

2. Khadrawy KH, Ahmed N, Aboul ezz H, radwan N (2009) Effect of electromagnetic radiation from mobile phone on the levels of cortical amino acid neurotransmitters in adult and young rats. Romanian J Biophys, 19(4): 295-305.

3. Lopez-Fernandez $\mathrm{O}$, Kuss $D$, Pontes $H$, Griffiths $M$, Dawes $C$, Justice L, Männikkö $N$, Kääriäinen $M$, Rumpf $H J$, Bischof A, Gässler AK (2018) Measurement invariance of the short version of the problematic mobile phone use questionnaire (PMPUQ-SV) across eight languages. Int J Environ Res Public Health, 15(6): 1213.

4. Cha SS, Seo BK (2018) Smartphone use and smartphone addiction in middle school students in Korea: Prevalence, social networking service, and game use. Health Psychol open, 5(1): 1-15.

5. de-Sola J, Talledo H, de Fonseca FR, Rubio G (2017) Prevalence of problematic cell phone use in an adult population in Spain as assessed by the Mobile Phone Problem Use Scale (MPPUS). PloS one, 12(8): 181-4.

6. Anand N, Jain PA, Prabhu S, Thomas C, Bhat A, Prathyusha PV, Bhat SU, Young K, Cherian AV (2018) Prevalence of excessive internet use and its association with psychological distress among university students in South India. Ind Psychiatry J, 27(1): 131. 
7. Nahas M, Hlais S, Saberian C, Antoun J (2018) Problematic smartphone use among Lebanese adults aged 18 to 65 years using MPPUS-10. Comput Human Behav, 87: 348-53.

8. Vernon L, Modecki KL, Barber BL (2018) Mobile phones in the bedroom: Trajectories of sleep habits and subsequent adolescent psychosocial development. Child development, 89(1): 66-77.

9. Thornton S (2018) Mobile phone use in children and young people: A public health concern? British J Sch Nur, 13(2): 94-7.

10. Kocaman A, Altun G, Kaplan AA, Deniz ÖG, Yurt KK, Kaplan $S$ (2018) Genotoxic and carcinogenic effects of nonionizing electromagnetic fields. Environ Res, 163: 71-9.

11. Lasalvia M, Scrima R, Perna G, Piccoli C, Capitanio N, Biagi PF, Schiavulli L, Ligonzo T, Centra M, Casamassima G, Ermini A (2018) Exposure to $1.8 \mathrm{GHz}$ electromagnetic fields affects morphology, DNA-related Raman spectra and mitochondrial functions in human lympho-monocytes. PloS one, 13(2): 1-26.

12. Al-Serori H, Ferk F, Kundi M, Bileck A, Gerner C, Mišík M, Nersesyan A, Waldherr $M$, Murbach $M$, Lah TT, HeroldMende C (2018) Mobile phone specific electromagnetic fields induce transient DNA damage and nucleotide excision repair in serum-deprived human glioblastoma cells. PloS one, 13(4): 1-17.

13. Sage $C$ and Burgio E (2018) Electromagnetic fields, pulsed radiofrequency radiation, and epigenetics: How wireless technologies may affect childhood development. Child development, 89(1): 129-36.

14. Poulsen AH, Friis S, Johansen C, Jensen A, Frei P, Kjær SK, Dalton SO, Schüz J (2013) Mobile phone use and the risk of skin cancer: a nationwide cohort study in Denmark. Am J Epidemiol, 178(2): 190-7.

15. Dodds M, Roland S, Edgar M, Thornhill M (2015) Saliva A review of its role in maintaining oral health and preventing dental disease. Bdj Team, 2: 1-13.

16. Arbabi-Kalati F, Salimi S, Vaziry-Rabiee A, Noraeei $M$ (2014) Effect of mobile phone usage time on total antioxidant capacity of saliva and salivary immunoglobulin A.
Iranian J Publ Health, 43(4): 480-4.

17. Hardell L, Carlberg M, Hansson M (2011) Pooled analysis of case-control studies on malignant brain tumours and the use of mobile and cordless phones including living and deceased subjects. Int J Oncol, 38(5): 1465-74.

18. Saeed S, Shaikh A, Noor SA (2017) Analysis of Brain Tumors Due to the Usage of Mobile Phones. Mehran Univ Res J Engineering and Technology, 36(3): 609.

19. Forouharmajd F, Pourabdian S, Ebrahimi H (2018) Evaluating temperature changes of brain tissue due to induced heating of cell phone waves. Int J Prev Med, 9(1): 1-40.

20. Khurana VG, Teo C, Kundi M, Hardell L, Carlberg M (2009). Cell phones and brain tumors: a review including thelongterm epidemiologic data. Surg Neurol, 72(1): 205-15.

21. de Souza FT, Correia-Silva JF, Ferreira EF, Siqueira EC, Duarte AP, Gomez MV, Gomez RS, Gomes CC (2014) Cell phone use and parotid salivary gland alterations: No Molecular Evidence. Cancer Epidemiol Biomarkers Prev, 23 (7): 1428-31.

22. Ranjitha GE, Austin RD, Ramasamy S, Bharathi CS, Angeline D, Sambasivam S (2017) Influence of Handheld Mobiles on Parotid: A Cohort Study. J Indian Academy of Oral Med and Radiology, 29(4): 254.

23. Goldwein O and Aframian DJ (2010) The influence of handheld mobile phones on human parotid gland secretion. Oral Dis, 16(2): 146-50.

24. Bhargava S, Motwani MB, Patni VM (2012) Effect of handheld mobile phone use on parotid gland salivary flow rate and volume. Oral Surg, Oral Med, Oral Pathol and Oral Radiol, 114(2): 200-6.

25. Hamzany $Y$, Feinmesser $R$, Shpitzer $T$, Mizrachi A, Hilly $O$, Hod R, Bahar G, Otradnov I, Gavish M, Nagler RM (2013) Is human saliva an indicator of the adverse health effects of using mobile phones? Antioxid Redox Signal, 18(6): 622-7.

26. Babaee N, Kazemi H, Sefidgar SA, Bijani A, Pouramir M, Mortazavi H, Ghasemi N (2016) Evaluation of the effect of handheld mobile phone use on activity of the parotid glands amylase enzyme. Caspian J Dent Res, 5(2): 37-43. 
